\title{
ESTIMATING THE EFFECTS OF INCOME ON FOOD CON- SUMPTION EXPENDITURE IN THE VOLTA REGION OF GHANA
}

\author{
W. Adzawla* and S. Kudadze \\ University for Development Studies, P. O Box TL1882, Nyankpala, Tamale \\ *Corresponding author: adzawlawilliam@gmail.com
}

\begin{abstract}
This study examined the effect of disaggregated income and other socioeconomic factors on per capita food consumption expenditure of households in the Volta region of Ghana. This involved a total of 1,574 households obtained from the Ghana Living Standard Survey round six data (GLSS6 data). A quantile regression and Ordinary Least Square regression were fitted to the data. The results showed that, income from agricultural activities, non-farm activities, remittances and wage activities had positive and significant effect on per capita food consumption expenditure of the selected households. The study concluded that although income from all sources led to an increase in food consumption expenditure, a larger share of agricultural income is used for households' food consumption purposes. To reduce households' vulnerability to food insecurity, price incentives to increase the real income from agriculture in particular should be promoted. Also, dietary education should be encouraged among households in the region.
\end{abstract}

Keywords: Key words: Food expenditure, income, quantile regression, Volta region

\section{INTRODUCTION}

Global progress in reducing hunger have being remarkable. About 56 percent of countries monitored by Food and Agriculture Organisation (FAO) have achieved the Millennium Development Goal (MDG) on halving food insecurity (undernourishment). Nonetheless, this global progress have been uneven, with very slow progress in sub-Saharan Africa (SSA) (FAO, 2015). Therefore, food security still remain one of the major developmental issues worldwide. The Sustainable Development Goal (SDGs) two aim at ending hunger and achiev- ing food security by 2030 . From FAO (2015), achieving a sustainable zero hunger requires an additional US\$265 billion per year, although the report was optimistic that this is a small price to pay to achieve such a vital goal.

Ghana has been fairly stable in terms of food security on national basis, although there are regional differences where pockets of food insecurity situations have been recorded especially in the three northern regions. World Food Program (WFP, 2009) indicated that $5 \%$ of Ghana's population is food insecure and an 
extra $8.3 \%$ are vulnerable to become food insecure if there is any man-made or natural shock occurrence. For most households in the country, hunger is frequently associated with poor harvests resulting from environmental degradation, poor weather, natural disasters and conflicts, among others. In recent times also, food security has been challenged by the changing climatic pattern and over reliance on rain-fed agriculture which led to seasonal food deficits.

Households make expenditure on a number of items. However, one of the major component of household expenditure is food. Food is a basic need of life. Food availability therefore affects other life decisions such as health status and education. Donkoh et al., (2014) found that as the share of household's food budget to total household expenditure increases, the welfare of the household decreases. Therefore, households' food expenditure have become a reliable indicator for measuring economic vulnerability (Babalola and Isitor, 2014). Similarly, the analysis of households' food consumption expenditure provides the understanding of how households cope with price changes and remain productive (Aminu et al., 2016). Engel's law provides the understanding that increases in income leads to less than proportionate increase in food consumption expenditure; exhibiting a nonlinear relationship.

The problem underlying this study is three folds. Firstly, previous studies used aggregated income to examine the effect of income on food expenditure (Namso et al., 2017; Koustakis, 2014; Ment et al., 2013; Caglayan and Astar, 2012; Aidoo et al., 2009). Venn et al., (2017) disaggregated total income into various quantiles and examined their share of impacts on consumption expenditure, but the sources of income were missing. Although these are no fallacy, they do not provide information on specific effect of income from different sources. The recommendation from these studies is that income increasing opportunities be made available to households, however, the income sources that should be promoted were not identified. Secondly, Meng et al., (2013) used quantile regression, whilst Donkoh et al. (2014) and Aidoo et al. (2009) used mean prediction models such as ordinary least squares
(OLS) to investigate food consumption expenditure in Ghana. However, households' food consumption may be heavy at the tails.

Therefore, identifying the drivers of food expenditure using these methods may not provide more reliable findings for policy makers. This study addressed these issues using disaggregated income from four different portfolios and estimating a quantile regression. The OLS estimates are also reported for more comprehensive understanding of the drivers of food consumption and comparison of findings. Finally, the search capacity of the researchers found no empirical work to examine the effect of income on food consumption expenditure of households in the Volta region of Ghana. Therefore, this study would be providing more relevant information on food consumption expenditure in the region. The findings and recommendations of this study would help policy makers interested in improving food consumption and welfare of households in the region to make informed decisions based on prioritisation of income sources to attain this objective.

The theoretical foundation of this study is the consumer theory. Households as consumers are rational in making decisions on the allocation of resources or budget to a basket of goods and services. This rationality is achieved through preferences. Consumer theory propounds that these preferences can be ordinal or cardinal. In both cases, the objective of the consumer is to maximise utility from the consumption of goods and services subject to the available budget. In most cases, the marginal utilities of food is positive. The household's utility is maximised subject to own price and income constraint. As income rises, the set of choices available to the consumer rises while increases in prices reduce consumer choices. However, because own prices vary less in cross sectional data (as in this study), consumer utility is maximised subject to income. Hence, the focus of this study is to estimate the effect of household's disaggregated income on food consumption expenditure in the Volta region of Ghana.

\section{Empirical review}

Over decades, there have been a long-standing research on the relationship between income 
and food consumption. According to Mignouna et al., (2015), economists have had the interest of identifying the factors that drive households' expenditure over the years. In Ghana, household consumption analysis has attracted several interest from both public and private sector players due to economic progress of the country in recent years (Meng et al., 2013). Research interest in this field is justifiable due to the significant recognition of food in consumption basket (Namso et al., 2017; Caglayan and Astar, 2012). As noted by Babalola and Isitor (2014), food consumption expenditure forms a greater proportion of households' consumption expenditure, therefore, the former can even be used as a proxy for the latter.

The analysis of food consumption patterns can offer the understanding of the causes of obesity (Fan et al., 2007). As a component of consumption expenditure, individuals and households make decisions based on factors such as income, price and socioeconomic conditions of the consumer (Caglayan and Astar, 2012). The implication is that consumers' welfare are maximized if consumption decisions are perfectly taken. Also, despite the fact that the income elasticity of demand for food is less than unitary (Namso et al., 2017; Babalola and Isitor, 2014; Umeh and Asogwa, 2012), the nutritional status of households are improved since the propensity to spend food budget on diversified diets is high (Babalola and Isitor, 2014). Caglayan and Astar (2012) noted that household consumption expenditure have had wide placement in the literature due to the fact that it changes with social, demographic, cultural and developmental policies. Thus, the purchasing behaviour, type and quality of diet differs among various groups in the society (Venn et al., 2017). Kostakis (2014) found that socioeconomic characteristics such as income, gender, age, marital status, place of residence and status of employment of household heads significantly influence households' consumption patterns. Donkoh et al., (2014) also found that sex, age, education, marital status, household size and location variables significantly influence the food consumption expenditure of Ghanaian households. Mignouna et al., (2015) reported that household expenditure increases for households with higher education and those whose primary occupation is not farming. Meng et. al, (2013) estimated a positive significant effect of education on food expenditure of $25^{\text {th }}$ and $50^{\text {th }}$ quantiles of urban households in Ghana. While the highly educated and high-income households consider food safety and adheres to food safety standards or dietary guidelines (Turrell et al., 2002). Generally, low income households consume below dietary guidelines (Venn et al., 2017).

In the early 1980s, Davis et al., (1983) found that although general education has no significant effect on food expenditure, homemakers with education on nutrition spend less on food expenditure since they are efficient in food purchasing. Therefore, general education may not be a good proxy for the level of stock of knowledge required for efficient decision making on food purchasing (Davis et al., 1983). On this basis, Venn et al., (2017) recommend the promotion of dietary education whilst Mignouna et al. (2015) and Umeh and Asogwa, (2012) recommend for addressing educational financing constraints, especially, for households with less education.

Umeh and Asogwa (2012) show that there is an inverse relationship between income and food expenditure, therefore, as household income increases, the expenditure on food decreases. On the contrary, Namso et al., (2017) estimated a positive effect of income on consumption expenditure of staple foods, beverages and meat or meat related products. Consistent with Engel's law, Namso et al. (2017) also estimated an inelastic income demand for food, and this was highest for beverages than staples. Yimer (2011) also found significant effect of socioeconomic factors on the food consumption expenditure of specific food crops. From Yimer (2011), income had positive effect on the consumption expenditure of teff while it had a negative effect on maize and sorghum consumption expenditure. To offset income inequality, Namso et al., (2017) recommended an imposition of taxes on high income households and subsidy programs for low and middle income households. This is consistent with the earlier findings of Davis et al., (1983) that food expenditure is more income inelastic for households who benefitted from food stamp programs. The 
poor usually spends high proportion of their income on food while the rich spends less proportion of their income on food. The work of Meng et al., (2013) found that an increase in the income of urban households leads to a high food consumption expenditure at every quantile, and this effect is higher for high income households than low income households.

A macro study by Gerbens-Leenes et al., (2010) revealed that food consumption pattern shows the same pattern with economic growth. This means that as economic growth progress, food consumption also increase. The authors also indicated that there is a global food transition towards effluent food consumption patterns. From a similar macro study, Rask and Rask (2011) concluded that food consumption pattern stabilizes at high income. Result from these previous studies show mixed effect of specific factors such as income on household food expenditure. However, Bouis (1994) argued that the widely income elasticity estimates from cross-sectional surveys are biased upwards since these surveys failed to adequately capture food transfer from high to low income groups. Santeramo and Shabnam (2015) also reviewed studies that examined income effect on consumption expenditure and concluded that the quality of data is vital to establish an accurate relationship, and as a result, found substantial publication bias. The advantage of this study is that a national data was used where much accuracy measures were considered. Therefore, the limitations as observed by Santeramo and Shabnam (2015) can be minimised.

\section{METHODOLOGY}

\section{Data sources and sample size}

The study used the Ghana Living Standard Survey round six data (GLSS6) that was collected in 2012/13. The data covers a wide range of household information including household expenditure. This study is based on only Volta region with a total sample of 1,574 household heads.

\section{Model specification}

One of the major limitations of previous studies that analysed the food consumption expenditure of households (Donkoh et al., 2014; Aidoo et $a l ., 2009)$ is the estimation at mean. These neglect the fact that household food expenditure may not be normally distributed around the mean food expenditure of the households, which also means that, the effect of independent variables may differ at different levels of the food consumption expenditure. Therefore, estimations at the mean may not provide adequate results. To resolve this, the present paper used quantile regression and OLS. The quantile regression allows the estimation of the factors that influence food consumption expenditure of households at different quantiles (lower $/ 1^{\text {st }}$, median $/ 2^{\text {nd }}$ and upper $/ 3^{\text {rd }}$ quantiles). This also provide complete analysis of the stochastic relationship among random variables and permits the estimation of conditional distribution of food consumption expenditure. Following Greene (2012), the quantile regression is generally specified as;

$y=X^{\prime} \beta+\varepsilon$

where $E(\varepsilon \mid X)=X^{\prime} \beta$. Given that $\varepsilon \mid X$ is normally distributed and symmetric, then the median $\operatorname{Med}(\varepsilon \mid X)$ is also zero and $\operatorname{Med}(\varepsilon \mid X)=X^{\prime} \beta$

The linear quantile regression is then given as;

$Q(y / X), q=X^{\prime} \beta$, = $\frac{\mathbf{1}}{2}$ if median; $\frac{\mathbf{1}}{\mathbf{4}}$ if lower

quantile; $\frac{3}{4}$ if upper quantile

Empirically,

Per capita food expenditure $=\beta_{0}+\beta_{1}$ Agricultural $\beta_{2}$ Non-farm $+\beta_{3}$ Re mit tan ce $+\beta_{4}$ Wage + $\beta_{5}$ Rural cos tal $+\beta_{6}$ Rural forest $+\beta_{7}$ Rural savanna $+\beta_{8}$ Household size $+\beta_{9}$ Education $+\beta_{10}$ Age $+\beta_{11}$ Male $+\beta_{12}$ Marital status

Description of variables

The dependent variable for this study is house- 
hold's per capita food expenditure: This is the total food expenditure of the household divided by adult equivalent household size. Food consumption expenditure is expected to vary with changes in the explanatory variables discussed below.

Household income: The total income of households is disaggregated into four major components. These are agricultural income (total annual gross income of household head from agricultural activities), non-farm income (total gross income of household head from non-farm economic activities), remittances (total remittances received by household head in the year) and wage income (total income of household head from wage activities). Although studies such as Namso et al., (2017) estimated the effect of total household income on food expenditure, the objective of the income disaggregation in this study is to examine the sources of income that households usually use more for food consumption purposes. Since these are all income sources, it is theoretically and empirically expected that they will have a positive effect on food consumption expenditure.

Location: The location of the household heads is clustered into three, coastal, forest and savannah zones. A household head in each of these clusters is either located in the rural area or the urban area. The classification of the households into zones or clusters is based on the fact that the food sources of households differ across the zones. Similarly, empirical studies revealed that food consumption expenditure is higher in urban areas, hence, the need to examine the urban -rural impacts on food consumption based on the zone location of the household. By definition, these variables are dummy and defined as one (1) for household heads located in rural areas and zero (0) if a household head is located in urban area. For instance, a household head located in rural areas of the coastal cluster is given 1 while those located in urban areas in the coastal zone are given 0 . These variables are hypothesised to be negative since household heads located in the rural areas may obtain some of their food from their own farms, hence, spend less on food than urban household heads who may have to buy all their food needs. Donkoh et al. (2014) used coastal and savannah locations and found an inverse relation between coastal and food expenditure but a direct relationship between savannah and food expenditure.

Household size: The household size is the total number of households that lives in the same household, sharing and pooling resources together. This is an important variable in food consumption analysis since every household member must be fed. Hypothetically, household size may exert positive effects on food consumption expenditure. Thus, as household size increases, the food expenditure of the household would also increase. This is because, an additional household member means that an additional food expenditure has to be made on that household member. Household size was used by Babalola and Isitor (2014) and Donkoh et al. (2014) and found positive and negative relationships with food consumption expenditure, respectively.

Education: Education of household head is defined as the total number of years a household head spent in a formal education. It is expected that the higher the education, the higher the desire for quality foods which would require more food expenditure. Similarly, the more educated household heads may naturally turn to expensive food products in order to maintain their social recognition. Empirically, Namso et al., (2017) estimated a positive significant effect of education on food consumption expenditure whilst Caglayan and Astar (2012) estimated a negative effect of education on food expenditure.

Age of household head: The age of the household head is defined as the total number of years of a household head from the time of birth to the time of data collection. Age is expected to have a positive effect on food expenditure. This is because, while the younger household heads may have to spend high amounts of their income on non-food products such as housing, furniture and clothing, the elderly household heads may have accumulated most of these assets and may devote much of their incomes to food consumption. Meng et al. (2013) used age in their study and found a positive effect on food expenditure at all 
quantiles.

Male: this is the biological description of a household head as a male or a female. It is a dummy variable that is defined as 1 if the household head is a male and 0 if the household head is a female. The variable 'male' is expected to have a negative effect on food consumption expenditure since females are generally inclined to making more positive food expenditure than males. Kostakis (2013) and Meng et al. (2013) used gender in similar studies and found negative relationships with household's expenditure on food.

Marital status: The current marital status of household head is categorised into six (6) groups: never married, married polygamous, married monogamous, common law or living together, divorced or separated, widow or widower. The group 'never married' was used as a reference group for the construction of dummy variables for the other five marital groups. The choice of the reference group is due to the fact that these household heads may have less biological obligations that would force their food consumption expenditure. Unlike studies such as Babalola and Isitor (2014) and Yimer (2011) that simply classified respondents' marital status as 'married' or 'single', the disaggregation in this study is justifiable since the actual marital status defines the consumption expenditure of the household head and not merely the fact that the household head is married or single. This disaggregation is consistent with that adopted by Caglayan and Astar (2012).

\section{Profile of Volta region}

The study is conducted in the Volta region of Ghana. The capital of the region is Ho. The recent housing and population census in 2010 provided that the region hosts $8.6 \%(2,118,252$ people) of Ghana's total population and has a population growth rate of 2.5 , same as the national population growth rate. Approximately $66 \%$ of the population lives in the rural areas (GSS, 2012). Also, 33.8 of the population are considered poor, and contributing $6.2 \%$ to Ghana's total poverty gap (GSS, 2014a). The mean annual household expenditure and mean annual per capita expenditure for the region are 8,217 Ghana cedis and 2,508 Ghana cedis, respecti- vely. The lowest quintile formed $18.9 \%$ of the population while the highest quintile is $20.8 \%$. Food account for $54 \%$ of the total household's budget, and this is the second highest (first by Upper East's 55.2\%) in the country. This is higher than Ghana's $46.7 \%$ food budget line. The main income sources for households in the region include non-farm self-employment $(39.8 \%)$, wage $(16.6 \%)$, agricultural $(7.6 \%)$ and the remaining percentage distributed among other sources such as remittances (GSS, 2014a). Major food staples include maize, rice, cassava and yam.

\section{RESULTS AND DISCUSSIONS \\ Descriptive statistics of variables}

Table 1 and 2 show the descriptive statistics of the respondents. From Table 1, the majority (66.1) of the household heads were males. Also, the highest percentage $(56.5 \%)$ of the respondents were married monogamously while as low as $3 \%$ and $7.4 \%$ of the sampled household heads were household heads with a polygamous marriage or had never married, respectively. The majority of the respondents in all zones were located in urban areas other than rural areas.

Table 2 shows that the average age of a household head is 48.15 years. The youngest and oldest household heads were 25 and 98 years old, respectively. Averagely, there are 4 members in each of the selected households. However, there are homes with only the household head while there are others with as many as 21 members. The average level of education of a household head is 7 years, indicating that the average household head had completed primary. Averagely, the annual per capita food expenditure of a household head is GHC1,322.47. The least per capita food expenditure made by a household head was GHC18.25 while the highest per capita food expenditure was GHC74,052.66. This shows a wide inequality among the sampled households. The highest source of income for a household head was from non-farm economic activities, followed by wage income, agricultural income and remittances. The high income from non-farm income can be due to the high engagement and reliance on informal activities such as trading and skilled jobs such as dressmaking. 
Effects of income on food consumption expenditure... 91

Table 1: Descriptive statistics of categorical variables

\begin{tabular}{lcccccc}
\hline & \multicolumn{2}{c}{ Yes } & \multicolumn{2}{c}{ No } & \multicolumn{2}{c}{ Total } \\
\hline & & & & & & \\
Variable & Freq. & $\%$ & Freq. & $\%$ & Freq. & $\%$ \\
Rural costal & 379 & 24.1 & 1195 & 75.9 & 1574 & 100.0 \\
Rural forest & 438 & 27.8 & 1136 & 72.2 & 1574 & 100.0 \\
Rural savanna & 244 & 15.5 & 1330 & 84.5 & 1574 & 100.0 \\
Male & 1041 & 66.1 & 533 & 33.9 & 1574 & 100.0 \\
Marital status: & & & & & & \\
Never married & 116 & 7.4 & 1458 & 92.6 & 1574 & 100.0 \\
Married monogamous & 889 & 56.5 & 685 & 43.5 & 1574 & 100.0 \\
Married polygamous & 47 & 3 & 1527 & 97 & 1574 & 100.0 \\
Common law or living together & 127 & 8.1 & 1447 & 91.9 & 1574 & 100.0 \\
Divorced & 169 & 10.7 & 1405 & 89.3 & 1574 & 100.0 \\
Widowed & 226 & 14.5 & 1348 & 85.5 & 1574 & 100.0 \\
\hline
\end{tabular}

Table 2: Summary statistics of continuous variables

\begin{tabular}{lcccc}
\hline Variable & Mean & Std Deviation & Minimum & Maximum \\
\hline Age & 48.15 & 16.71 & 25.00 & 98.00 \\
Household size & 4.23 & 2.85 & 1.00 & 21.00 \\
Education & 6.67 & 5.09 & 0.00 & 19.00 \\
Per capita food expenditure & $1,322.47$ & $2,280.41$ & 18.25 & $74,052.66$ \\
Agricultural & $2,372.81$ & $8,145.87$ & 0.00 & $157,843.70$ \\
Non-farm & $6,720.42$ & $32,750.20$ & 0.00 & $743,280.80$ \\
Remittance & 220.86 & 538.12 & 0.00 & $7,350.00$ \\
Wage & $5,323.92$ & $19,031.33$ & 0.00 & $452,100.00$ \\
\hline
\end{tabular}

\section{Regression results}

The estimated results of OLS and quantile regression are shown in Table 3 below. The goodness of fit of the models was higher for the OLS model (37.4\%) and lowest for the first quantile models $(22.1 \%)$. The variables can generally be put into three categories, income variables, location variables and demographic variables. Among the income variables, income from agriculture, nonfarm activities, remittance and wages had positive significant effect on food expenditure in the OLS or 
quantile models or both. Only rural forest was significant and negative among the location variables. Among the socioeconomic variables, education and polygamous marital status had positive effects on food consumption expenditure while household size, being a male household head, monogamous marital status, married but divorced or being a widow/widower had negative significant effect on households' food consumption expenditure.

\section{Effect of income on food expenditure}

From table 3, agricultural income had a positive significant effect on food consumption expenditure in all models. these are significant at $1 \%$. this means that household heads with higher income from agricultural activities have higher expenditure on food. the impact of agricultural income is highest for the first quantile households with an elasticity of $8.9 \%$. Thus, a $100 \%$ increase in agricultural income leads to $8.9 \%$ increase in food expenditure among the households in the first quantile while that of the second and third quantiles are $7.7 \%$ and $8.4 \%$, respectively. The estimated positive elasticities may be due to consumption of own-produced agricultural commodities. In most cases where farmers consume own produced commodities, food wastage tends to be high. Contrarily, households who buys food commodities are usually more conscious of the expenditure on food. This explains that the general observation of farmers as poorer households is centred on issues around own consumption. Contrary to this study, Yimer (2011) found that selfemployment had a negative effect on food consumption expenditure.

Income from non-farm activities also had a positive significance, at $1 \%$, on food expenditure in all models except in the third quantile model that was insignificant, although positive. The effect is however higher for households located at the median than the first quantile households. A $100 \%$ increase in nonfarm income leads to a $0.2 \%$ and $0.16 \%$ increase in food expenditure among the first and second quantile households respectively. Non-farm activities are an important sources of an additional income for many households, especially, farm households. The insignificance of the variable in the upper quantile model suggests that nonfarm income activities have more effects on households with lower food expenditure than those with higher food expenditure. Thus, in promoting nonfarm activities, households with lower food expenditure should be targeted. This is consistent with the findings of Talukder and Chile (2013).

Remittances had a positive effect on the food expenditure of only households in the lower quantile but the significance is weak $(10 \%)$. Although the sources of remittances were not examined in this study, the finding implies that remittance leads to a higher food consumption expenditure. Thus, a 100\% increase in remittances could lead to $1.4 \%$ increase in household food expenditure. Umeh and Asogwa (2012) also estimated a positive effect of income from transfers on food consumption expenditure, although this was not significant for their study. Contrarily, Talukder and Chile (2013) found that remittances lead to a decline in the growth of consumption expenditure.

Wage income had positive significant effect, at $1 \%$, on household food expenditure in all models. Thus, as wage income increases, food expenditure also increases. The effect was higher for the lower $(2.7 \%)$ and upper quantile $(2.7 \%)$ than for the median quantile $(2.2 \%)$. Talukder and Chile (2013) found that income from wage activities can lead to an increase in the growth of consumption expenditure of households. Contrary, Yimer (2011) found that working as a public employee or an NGO employee decreases the consumption expenditure of the household.

\section{Effect of demographic and location factors on food expenditure}

Table 3 shows that households located in rural forest spend less on food consumption than their urban counterparts or households located elsewhere in the region. Thus, the variable, rural forest significantly influences food consumption expenditure at $1 \%$ in all models. Although food production is a major economic activity of the households in the Volta region, it is more common for the rural households than the urban households (GSS, 2014a). Similarly, the cultivation of food crops such as maize and cassava are common for households located in 
Effects of income on food consumption expenditure... 93

Table 3: Factors influencing household's per capita food expenditure

\begin{tabular}{|c|c|c|c|c|c|c|c|c|}
\hline \multirow[b]{3}{*}{ Variable } & \multirow{3}{*}{$\begin{array}{l}\text { OLS } \\
\text { Coeff. }\end{array}$} & \multirow[b]{3}{*}{$\begin{array}{l}\text { P- } \\
\text { Value }\end{array}$} & \multicolumn{4}{|c|}{ Quantile regression } & \multirow{2}{*}{\multicolumn{2}{|c|}{$3^{\text {rd }}$ quantile (75\%) }} \\
\hline & & & \multicolumn{2}{|c|}{$1^{\text {st }}$ quantile ( $\left.25 \%\right)$} & \multicolumn{2}{|c|}{$2^{\text {nd }}$ quantile $(50 \%)$} & & \\
\hline & & & Coeff. & $\begin{array}{l}\text { P- } \\
\text { Value }\end{array}$ & Coeff. & $\begin{array}{l}\text { P- } \\
\text { Value }\end{array}$ & \multirow[t]{2}{*}{ Coeff. } & P-Value \\
\hline \multicolumn{8}{|l|}{ Income } & \\
\hline Agriculture & $\begin{array}{l}0.094 \\
(0.006)\end{array}$ & 0.000 & $\begin{array}{l}0.089 \\
(0.010)\end{array}$ & 0.000 & $\begin{array}{l}0.077 \\
(0.009)\end{array}$ & 0.000 & $\begin{array}{l}0.084 \\
(0.008)\end{array}$ & 0.000 \\
\hline Non-farm & $\begin{array}{l}0.016 \\
(0.005)\end{array}$ & 0.000 & $\begin{array}{l}0.016 \\
(0.005)\end{array}$ & 0.002 & $\begin{array}{l}0.020 \\
(0.005)\end{array}$ & 0.000 & $\begin{array}{l}0.004 \\
(0.006)\end{array}$ & 0.421 \\
\hline Remittance & $\begin{array}{l}0.010 \\
(0.006) \\
0.026\end{array}$ & 0.109 & $\begin{array}{l}0.014 \\
(0.008) \\
0.027\end{array}$ & 0.070 & $\begin{array}{l}0.012 \\
(0.008) \\
0.022\end{array}$ & 0.139 & $\begin{array}{l}0.007 \\
(0.008) \\
0.027\end{array}$ & 0.373 \\
\hline Wage & $(0.005)$ & 0.000 & $(0.008)$ & 0.000 & $(0.007)$ & 0.001 & $(0.008)$ & 0.001 \\
\hline $\begin{array}{l}\text { Location: } \\
\text { Rural costal }\end{array}$ & $\begin{array}{l}0.042 \\
(0.047)\end{array}$ & 0.372 & $\begin{array}{l}0.069 \\
(0.049)\end{array}$ & 0.157 & $\begin{array}{l}0.080 \\
(0.058)\end{array}$ & 0.172 & $\begin{array}{l}-0.029 \\
(0.056)\end{array}$ & 0.605 \\
\hline Rural forest & $\begin{array}{l}-0.35 \\
(0.044) \\
-0.084\end{array}$ & 0.000 & $\begin{array}{l}-0.388 \\
(0.051) \\
-0.110\end{array}$ & 0.000 & $\begin{array}{l}-0.360 \\
(0.060) \\
0.005\end{array}$ & 0.000 & $\begin{array}{l}-0.371 \\
(0.056) \\
-0.003\end{array}$ & 0.000 \\
\hline $\begin{array}{l}\text { Rural savanna } \\
\text { Demographics }\end{array}$ & $(0.060)$ & 0.160 & $(0.086)$ & 0.203 & $(0.083)$ & 0.949 & $(0.079)$ & 0.972 \\
\hline $\begin{array}{l}\text { Household } \\
\text { size }\end{array}$ & $\begin{array}{l}-0.662 \\
(0.028)\end{array}$ & 0.000 & $\begin{array}{l}-0.647 \\
(0.036)\end{array}$ & 0.000 & $\begin{array}{l}-0.740 \\
(0.035)\end{array}$ & 0.000 & $\begin{array}{l}-0.671 \\
(0.039)\end{array}$ & 0.000 \\
\hline Education & $\begin{array}{l}0.082 \\
(0.019)\end{array}$ & 0.000 & $\begin{array}{l}0.093 \\
(0.025)\end{array}$ & 0.000 & $\begin{array}{l}0.077 \\
(0.026)\end{array}$ & 0.003 & $\begin{array}{l}0.095 \\
(0.024)\end{array}$ & 0.000 \\
\hline Age & $\begin{array}{l}0.060 \\
(0.058)\end{array}$ & 0.299 & $\begin{array}{l}0.125 \\
(0.077)\end{array}$ & 0.103 & $\begin{array}{l}0.014 \\
(0.063)\end{array}$ & 0.822 & $\begin{array}{l}0.085 \\
(0.081)\end{array}$ & 0.294 \\
\hline Male & $\begin{array}{l}-0.145 \\
(0.044)\end{array}$ & 0.001 & $\begin{array}{l}-0.134 \\
(0.058)\end{array}$ & 0.022 & $\begin{array}{l}-0.070 \\
(0.060)\end{array}$ & 0.244 & $\begin{array}{l}-0.124 \\
(0.076)\end{array}$ & 0.105 \\
\hline Marital status: & & & & & & & & \\
\hline $\begin{array}{l}\text { Married } \\
\text { monogamous }\end{array}$ & $\begin{array}{l}-0.216 \\
(0.075)\end{array}$ & 0.004 & $\begin{array}{l}-0.263 \\
(0.082)\end{array}$ & 0.001 & $\begin{array}{l}-0.088 \\
(0.079)\end{array}$ & 0.265 & $\begin{array}{l}-0.220 \\
(0.113)\end{array}$ & 0.052 \\
\hline $\begin{array}{l}\text { Married } \\
\text { polygamous }\end{array}$ & $\begin{array}{l}0.211 \\
(0.129)\end{array}$ & 0.103 & $\begin{array}{l}0.075 \\
(0.199)\end{array}$ & 0.707 & $\begin{array}{l}0.409 \\
(0.165)\end{array}$ & 0.013 & $\begin{array}{l}0.309 \\
(0.186)\end{array}$ & 0.096 \\
\hline $\begin{array}{l}\text { Common law } \\
\text { or living } \\
\text { together }\end{array}$ & $\begin{array}{l}-0.122 \\
(0.088)\end{array}$ & 0.164 & $\begin{array}{l}-0.117 \\
(0.095)\end{array}$ & 0.219 & $\begin{array}{l}-0.084 \\
(0.098)\end{array}$ & 0.390 & $\begin{array}{l}-0.021 \\
(0.113)\end{array}$ & 0.854 \\
\hline Divorced & $\begin{array}{l}-0.196 \\
(0.086)\end{array}$ & 0.022 & $\begin{array}{l}-0.166 \\
(0.089)\end{array}$ & 0.062 & $\begin{array}{l}-0.023 \\
(0.103)\end{array}$ & 0.823 & $\begin{array}{l}-0.166 \\
(0.125)\end{array}$ & 0.185 \\
\hline Widowed & $\begin{array}{l}-0.277 \\
(0.090)\end{array}$ & 0.002 & $\begin{array}{l}-0.334 \\
(0.105)\end{array}$ & 0.002 & $\begin{array}{l}-0.157 \\
(0.103)\end{array}$ & 0.128 & $\begin{array}{l}-0.279 \\
(0.122)\end{array}$ & 0.022 \\
\hline $\begin{array}{l}\text { Constant } \\
\text { Adj. R sq }\end{array}$ & $\begin{array}{l}6.924 \\
(0.211) \\
37.4 \%\end{array}$ & 0.000 & $\begin{array}{l}6.299 \\
(0.264)\end{array}$ & 0.000 & $\begin{array}{l}7.092 \\
(0.234)\end{array}$ & 0.000 & $\begin{array}{l}7.314 \\
(0.325)\end{array}$ & 0.000 \\
\hline Pseudo R sq. & & & $22.1 \%$ & & $22.7 \%$ & & $22.7 \%$ & \\
\hline
\end{tabular}

NOTE: Standard errors are in parentheses 
rural forest areas. This, the estimated negative effect of rural forest on food consumption expenditure is plausible since these household heads may not make high expenditure of food consumption directly. The implication is that rural households in the rural forest belt of the region should be given attention to enhance their consumption. Contrary to this study, Caglayan and Astar (2012) reported that households located in urban areas spend high on food.

Household size was significant at $1 \%$ in all models and had a negative sign. This suggests that households with many members have less per capita food expenditure. Although the total expenditure of these large households may be higher, the relative or per capita expenditure may be lower. Two issues are plausible in explaining this outcome. The first is that larger households may spend on less expensive food commodities in order to maximise their food expenditure. Secondly, the rate of increase in food consumption expenditure may be less than unitary, thus, if the household size increased by $100 \%$, the expenditure on food would increase at a percentage less than 100 . The elasticity of household size was higher for the median $(74 \%)$ than the upper $(67.1 \%)$ and the lower $(64.7 \%)$ quantiles. This is consistent with Donkoh et al. (2014) who argued that resources are limited with increasing size of the household. Contrary to this study, Babalola and Isitor (2014), Sekhampu (2012) and Jacobson et. al. (2010) found a positive effect on consumption expenditure

From the regression result, education was significantly different from zero at $1 \%$. The data revealed that household heads with some level of formal education spends 190.80 Ghana cedis annually on food more than household heads with no formal education. Similarly, the study by Meng et al., (2013) revealed that educated households spends 2.17 Ghana cedis weekly (equivalent of 112.84 Ghana cedis annually) on fresh vegetables than household heads with no formal education. This is consistent with the positive effect of education on households' food expenditure. This is a confirmation on the importance of formal education in improving household welfare, economic growth and development. Consistently, the elasticity of edu- cation was higher for the upper quantile households. Most educated Ghanaian households spend high amounts on food consumption since they aim at consuming 'quality' food commodities. Namso et al., (2017) and Yimer (2011) also estimated that education have a positive significant effect on food consumption expenditure. However, this is contrary to the findings in Donkoh et al. (2014) and Caglayan and Astar (2012).

Household's headed by males have less food expenditure. But this was significant for the lower quantile households at 5\% significance level. This means that the sex of the household head does not have significant effect on food expenditure if the expenditure level of the household is high. Thus, gendered food inequalities can only be significantly observed among households with lower food consumption expenditure. The negative outcome in the lower quantile suggests that measures such as Livelihood Empowerment Against Poverty (LEAP) that seeks to address welfare inequalities, especially, among the women is in the right direction and this objective can better be achieved if the poorer households are targeted. This is consistent with studies that argued that household welfare and food production could be improved if women are given equal decision making and resource opportunities. Donkoh et al. (2014) and Ymer (2011) also reported that female headed households have higher food expenditure. This finding is similar to the findings of Kostakis (2013) and Caglayan and Astar (2012). Similarly, Meng et al., (2013) found that male headed households spend 1.19 Ghana cedis every week on fresh vegetables less than those headed by females.

Marital status have mixed implications and mixed empirically observed effects on food expenditure (see Donkoh et al., 2014; Meng et al., 2013; Sekhampu, 2012). These studies divided household heads or respondents into married and single group, however, this study put the various household heads into their actual current marital status since this is believed to provide more practical findings. Household heads who had monogamous marriage have less per capita food consumption expenditure than the household heads who have never mar- 
ried. This could be due to the fact that food consumption decision making among these households may be efficient between the household head and the spouse. This was significant at $1 \%$ for the lower quantile, significant at $5 \%$ for the upper quantile and not significant for the median households. Contrarily, polygamous married household heads had higher per capita food expenditure. This was significant at 5\% and $10 \%$ for the median and upper quantiles, respectively. Like monogamous married household heads, divorced (significant for only lower quantile at $10 \%$ ) and widowed (significant at $1 \%$ and $5 \%$ respectively for lower and upper quantiles) household heads have less per capita food expenditure. This is consistent with the finding of Caglayan and Astar (2012) that household heads who are single make higher food expenditure than those household heads that have other marital statuses.

\section{CONCLUSION AND POLICY IMPLICA- TIONS}

This study analysed food consumption expenditure among households in the Volta region of Ghana. One of the major and basic component of household consumption expenditure is food expenditure. Given the central role of food in human and economic development, research focus on food expenditure is vital for sustainable development. A consistent finding was the positive influence of income on the level of food expenditure. Unlike previous studies (Namso et al., 2017; Ment et al., 2013; Aidoo et al., 2009) that used total income, this study disaggregated income sources and examined their specific impacts on food consumption expenditure. It is concluded that income from agricultural activities had the highest impact on per capita food expenditure. Perhaps, agricultural income could have less impact if other components of household expenditure such as non-food or total consumption expenditure were used. This provide more specific finding and call for support to enhance farming households' consumption expenditure in other components. However, the positive significance of all income sources on food expenditure support recommendations on livelihood diversification as a strategy to improve household welfare, reduce risk and vulnerability.

It is also recommended that the effect of in- come on non-food consumption expenditure should be investigated to complement the findings in this study. Equally important and consistent with earlier studies is the positive effect of education and the negative effect of household size on food consumption expenditure. This draws and support previous study on the importance of formal education in household and the general economic development of the country. Educational programs especially on diets should be promoted in the region. To reduce households' vulnerability to food insecurity, price incentives to increase the real income from the various income sources, especially, agriculture should also be promoted.

\section{REFERENCES}

Aminu, F. O., Adebanjo, O. A., and Mohammed, H. A. (2016). Determinants of food expenditure patterns among households in Oshodi-Isolo local government area of Lagos State, Nigeria. Nigerian Journal of Agriculture, Food and Environment, 12(2): 98-102.

Aidoo, R., Nurah, G. K., Fialor ,S. C. and Ohene-Yankyera, K. (2009). Determinants of diary consumption expenditure in urban communities of southern Ghana. Journal of Science and Technology, 29(1): 87-96.

Babalola, D. A., and Isitor, S. U. (2014). Analysis of the determinants of food expenditure patterns among urban households in Nigeria : Evidence from Lagos State . Journal of A griculture and Veterinary Science, 7(5), 71-75.

Besaanko, D., and Braeutigam, R. R. (2011). Microeconomics (fourth edi). John Wiley and Sons, Inc.

Bouis, H. E. (1994). The effect of income on demand for food in poor countries: Are our food consumption databases giving us reliable estimates? Journal of Development Economics, 44: 199-226.

Caglayan, E. and Astar ,M. (2012). A microeconometric analysis of household consumption expenditure determinants for both rural and urban areas in Turkey. American International Journal of Contemporary Research, 2 (2): $27-34$. 
Davis , C. G., Moussie, M., Dinning ,J. S. and Christakis, G. J. (1983). Socioeconomic Determinants of Food Expenditure Patterns among Racially Different Low-Income Households: An Empirical Analysis. Western Journal of Agricultural Economics, 8 (2): 183-196..

Donkoh, S. A., Alhassan, H., and Nkegbe, P. K. (2014). Food expenditure and household welfare in Ghana. African Journal of Food Science, 8(3): 164-175. https:// doi.org/10.5897/AJFS2013.1120.

Fan, J. X., Brown, B. B., Kowaleski-Jones, L. Ken, R. Smith, and Zick, C. D. (2007). Household food expenditure patterns: A cluster analysis. Monthly Labor Review, pp. 38-51.

FAO. (2015). The State of Food and A griculture 2015. Social protection and agriculture: Breaking the cycle of rural poverty. Sofa.

Gerbens-Leenes, P.W., Nonhebel, S. and Krol M.S. Food consumption patterns and economic growth. Increasing affluence and the use of natural resources. Appetite, 55, 597608. doi:10.1016/j.appet.2010.09.013.

Greene, W. H. (2012). Econometric analysis (Seventh ed). England: Pearson Education Limited.

GSS. (2012). 2010 population and housing census: summary report of final results. Accra.

GSS. (2014a). Ghana living standards survey round 6 (GLSS6): Poverty profile in Ghana (2005-2013). Accra.

GSS. (2014b). Ghana living standards survey round 6 (GLSS 6) Main report. Accra, Ghana.

Jacobson, D., Mavrikiou, P. M., and Minas, C. (2010). Household size , income and expenditure on food: The case of Cyprus. Journal of Socio-Economics, 39(2): 319328. j.socec.2009.12.009
Jehle, G. A., and Reny, P. J. (2011). Advanced microeconomic theory (third edit). England: Pearson Education Limited.

Kostakis, I. (2013). The determinants of households' food consumption in Greece. International Journal of Food and Agricultural Economics, 2(2): 17-28.

Koustakis, I. (2014). The determinants of households' food consumption in Greece. International Journal of Food and Agricultural Economics, 2(2): 17-28.

Meng, T., Florkowski, W. J., Sarpong, D., Resurreccion, A. V. A.. and Chinnan, M. (2013). The determinants of food expenditures in the urban households of ghana: A quantile regression approach Ting. In $\mathrm{Se}$ lected Paper prepared for presentation at the Southern Agricultural Economics Association (SAEA) Annual Meeting, Orlando, Florida, 3--5 February, 2013. pp. 1-17.

Mignouna, D. B., Abdoulaye, T., Alene, A., Manyong, V. M., Dontsop, P. N., Ainembabazi ,J. H. and Aseidu, R.(2015). A microeconometric analysis of household consumption expenditure determinants in yam-growing areas of Nigeria and Ghana. Tropicultura, 33(3): 226-237.

Namso, N. F, Nsikan, B. and Kesit, K. N . (2017). Determinants of household expenditure on some major food items in Uyo Metropolis, Akwa Ibom State, Nigeria. A sian Journal of Agriculture and Food Sciences, 5 (6): $234-240$.

Rask, K. J. and Rask, N. (2011). Economic development and food productionconsumption balance: A growing global challenge. Food Policy, 36: 186-196. doi:10.1016/j.foodpol.2010.11.015.

Santeramo, F.G. and Shabnam, N. (2015). The income-elasticity of calories, macro- and micro nutrients: What is the literature telling us? Food Research International http:// dx.doi.org/10.1016/j.foodres.2015.04.014.

Sekhampu, T. J. (2012). Socio-economic deter- 
of household food expenditure in a low income township in South Africa. Mediterranean Journal of Social Sciences, 3(9): 449-454. https://doi.org/10.5901/mjss.2012.v3n3p449.

Talukder, D. and Chile, L. (2013). Determinants of Growth in Consumption of Rural Household in Bangladesh: A Regression Analysis. Talukder and Chile, International Journal of Applied Economics, 10(1): 39-63.

Turrell, G., Hewitt, B., Patterson, C., Oldenburg, B. and Gould, T. (2002). Socioeconomic differences in food purchasing behaviour and suggested implications for diet-related health promotion. Journal of Human Nutrition and Dietetics, 15: 355-364. doi:10.1046/ j.1365-277X.2002.00384.x.

Umeh, J. C. and Asogwa, C. C. (2012). Determinants of farm household food expenditure: implications for food security in rural Nigeria. International Conference on Ecology, Agriculture and Chemical Engineering (ICEACS'2012) December 18-19, 2012 Phuket (Thailand), pp. 212-217.

Venn, D., Dixon J., Banwell, C. and Strazdins, L. (2017). Social determinants of household food expenditure in Australia: the role of education, income, geography and time. Public Health Nutrition, 1-10. doi:10.1017/ S1368980017003342.

World Food Programme (WFP). (2009). Comprehensive food security and vulnerability analysis. Accra, Ghana.

Yimer, S. (2011). Determinants of food consumption expenditure in Ethiopia. International Journal of Economic Research, 2(5): 151-165. 